\title{
23. SEDIMENTOLOGY AND DOWNHOLE LOG ANALYSIS OF SITE 820, CENTRAL GREAT BARRIER REEF OUTER SHELF: THE FACTORS CONTROLLING PLEISTOCENE PROGRADATIONAL AND AGGRADATIONAL SEISMIC GEOMETRY ${ }^{1}$
}

\author{
David A. Feary ${ }^{2}$ and Richard D. Jarrard ${ }^{3}$
}

\begin{abstract}
The textural and compositional characteristics of the $400 \mathrm{~m}$ sequence of Pleistocene wackestones and packstones intersected at Ocean Drilling Program (ODP) Site 820 reflect deposition controlled by fluctuations in sea-level, and by variations in the rate of sediment supply. The development of an effective reefal barrier adjacent to Site 820, between $760 \mathrm{k} . \mathrm{y}$. and $1.01 \mathrm{Ma}$, resulted in a marked reduction in sediment accumulation rates on the central Great Barrier Reef outermost shelf and upper slope. This marked change corresponds with the transition from sigmoidal prograding seismic geometry in the lower $254 \mathrm{~m}$ of the sequence, to aggradational geometry in the top $146 \mathrm{~m}$.

The reduction in the rate of sediment accumulation that followed development of the reefal barrier also caused a fundamental change in the way in which fluctuations in sea-level controlled sediment deposition. In the lower, progradational portion of the sequence, sea-level cyclicity is represented by superimposed coarsening-upward cycles. Although moderately calcareous throughout (mostly $35 \%-75 \% \mathrm{CaCO}_{3}$ ), the depositional system acted in a similar manner to siliciclastic shelf depositional systems. Relative sea-level rises resulted in deposition of more condensed, less calcareous, fine, muddy wackestones at the base of each cycle. Sea-level highstands resulted in increased sedimentation rates and greater influx of coarse bioclastic material. Continued high rates of sedimentation of both coarse bioclastic material and mixed carbonate and terrigenous mud marked falling and low sea-levels. This lower part of the sequence therefore is dominated by coarse packstones, with only thin wackestone intervals representing transgressions.

In contrast, sea-level fluctuations following formation of an effective reefal barrier produced a markedly different sedimentary record. The more slowly deposited aggradational sequence is characterized by discrete thin interbeds of relatively coarse packstone within a predominantly fine wackestone sequence. These thin packstone beds resulted from relatively low sedimentation rates during falling and low sea-levels, with much higher rates of muddy sediment accumulation during rising and high sea-levels. The transition from progradational to aggradational sequence geometry therefore corresponds to a transition from a "siliciclastic-type" to a "carbonate-type" depositional system.
\end{abstract}

\section{INTRODUCTION}

Site 820 is located in a water depth of $278 \mathrm{~m}$ on the outermost shelf, about $8 \mathrm{~km}$ northeast of the outer Great Barrier Reef and $48 \mathrm{~km}$ northeast of the Australian coastline (Fig. 1). It is the central of three sites that form an outer shelf-to-upper slope drilling transect adjacent to Grafton Passage, a navigable channel through the outer Great Barrier Reef. The principal aim of this transect was to understand the relationship between seismic geometries, outer shelf/upper slope sedimentation, and rapid changes in global sea-level (Davies, McKenzie, PalmerJulson, et al., 1991). The particular objectives at Site 820 (Feary et al., 1990; Davies, McKenzie, Palmer-Julson, et al., 1991) were as follows:

1. To determine the age and facies of central portions of the aggradational and progradational units immediately in front of the present-day Great Barrier Reef.

2. To determine the relationship between sea-level and depositional facies to extract the sea-level signature.

3. To determine the timing and factors controlling the initiation of reef growth on the central Great Barrier Reef.

4. To understand the factors controlling the transition from prograding to aggrading depositional geometries.

Drilling at Site 820 fulfilled each of these objectives, providing an excellent high resolution record of outer-shelf and upper-slope sedimentation throughout much of the Pleistocene.

\footnotetext{
${ }^{1}$ McKenzie, J.A., Davies, P.J., Palmer-Julson, A., et al., 1993.Proc, ODP, Sci, Results, 133: College Station, TX (Ocean Drilling Program).

${ }^{2}$ Division of Marine Geosciences and Petroleum Geology, Australian Geological Survey Organisation (formerly Bureau of Mineral Resources), Canberra, Australia.

${ }^{3}$ Department of Geology and Geophysics, University of Utah, Salt Lake City, UT, U.S.A.
}

The characteristics of the progradational and aggradational seismic sequences intersected by Sites 819 to 821 are described more fully in Feary, Symonds, et al. (this volume). Although each of these holes intersected essentially the same sequence, Site 820 provides the best opportunity for detailed lithofacies-seismic correlation, as it intersects more of the seismic sequences than Site 819 , without the difficulties in along-strike correlation arising from slide planes cutting through the uppermost part of the sequence (see Feary, Symonds, et al., this volume). In addition, more of the seismic sequences are visible above the obscuring effects of the first multiple on seismic sections (Fig. 2), as a consequence of its greater depth compared with Site 821 .

The sequence cored at Site 820 was deposited entirely within the Pleistocene. Calcareous nannofossil studies (Davies, McKenzie, Palmer-Julson, et al., 1991; Wei and Gartner, this volume) show that the lowermost sediments intersected are above the Calcidiscus macintyrei first appearance datum (FAD) at $1.48 \mathrm{Ma}$. Microfossil preservation varied from excellent in the more clay-rich intervals to poor in coarsergrained intervals. Nannofossils provide a relatively coarse biostratigraphy for Site 820 (Fig. 3), with datums at 12.1 meters below seafloor (mbsf) (Emiliania huxleyi Acme, $0.075 \mathrm{Ma}$ ); $35.8 \mathrm{mbsf}$ (Emiliania huxleyi last appearance datum [LAD],0.275 Ma); $107.1 \mathrm{mbsf}$ (Pseudoemiliania lacunosa FAD, $0.465 \mathrm{Ma}$ ); 163 mbsf (Gephyrocapsa spp. C-D LAD, $0.92 \mathrm{Ma}$ ); $260.3 \mathrm{mbsf}$ (Gephyrocapsa spp. A-B FAD, 1.10 $\mathrm{Ma}$ ); and at $271.7 \mathrm{mbsf}$ (Helicosphaera selli FAD, 1.27 Ma). Planktonic foraminifers do not provide a more detailed basis for dating cores (Davies, McKenzie, Palmer-Julson, et al., 1991).

This study further amplifies and develops the brief lithofacies descriptions presented in the Leg 133 Initial Reports volume (Davies, McKenzie, Palmer-Julson, et al., 1991). We present detailed compositional and textural data from post-cruise laboratory studies, together with an analysis of the correspondence between lithofacies and downhole logs. 


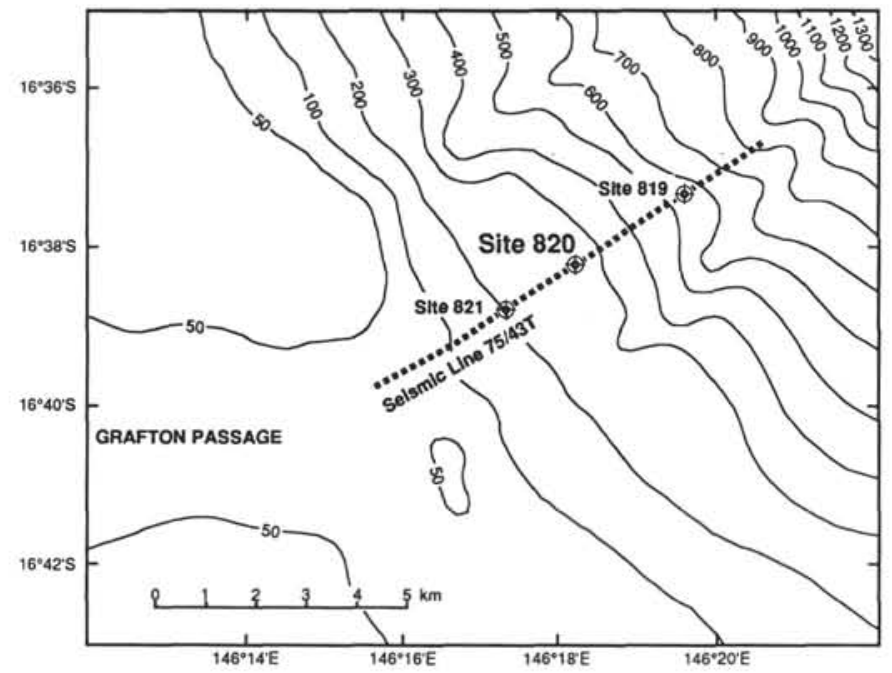

Figure 1. Location of Site 820 on the central Great Barrier Reef outermost slope/upper shelf. The track of BMR seismic line 75/43T (see Fig. 2) and location of adjacent Sites 819 and 821 also are shown. Bathymetry in meters.

The Dunham (1962) limestone classification, as modified by Embry and Klovan (1971), has been used for lithofacies description throughout this study, despite relatively low carbonate values $(<40 \%)$ within some finer-grained intervals. This approach was adopted to avoid confusion between carbonate "mudstones" within more calcareous intervals, representing mud-supported lithologies having less than $10 \%$ grains in the medium silt and finer classes $(<31 \mu \mathrm{m})$, and siliciclastic mudstones in less calcareous intervals that can include coarse silt (i.e., grain-sizes $<63 \mu \mathrm{m}$ ). Note that the suffix "-stone" has no firmness connotations (see Davies, McKenzie, Palmer-Julson, et al., 1991). Because such a large proportion of lithologies recovered at Site 820 are wackestones, variations in grain-size within this broad class have been recognized by informal subdivision into fine wackestones (maximum grain-size $<125 \mu \mathrm{m}$ ) and coarse wackestones (maximum grain-size $>125 \mu \mathrm{m}$ ).

\section{METHODS}

Hydraulic piston coring of the first hole at Site 820 (Hole 820A) obtained $100 \%$ recovery of the uppermost $140 \mathrm{~m}$ of section (Davies, McKenzie, Palmer-Julson, et al., 1991). Once the limit of the hydraulic piston corer was reached, vibrapercussive drilling was continued to the bottom of Hole $820 \mathrm{~A}$ at $144 \mathrm{mbsf}$. Hole $820 \mathrm{~B}$ was drilled some $20 \mathrm{~m}$ to the west of $820 \mathrm{~A}$, obtaining $100 \%$ recovery to $160 \mathrm{mbsf}$ using the hydraulic piston corer. Continued drilling using the extended core barrel averaged $68 \%$ recovery to the total depth at $400 \mathrm{mbsf}$.

\section{Analysis of Sediment Samples}

The textural and compositional data presented here are based on the analysis of 297 core samples from Holes 820A and 820B. Half of each sample (the working half) was disaggregated and wet-sieved into gravel and sand $(>63 \mu \mathrm{m})$ and mud $(<63 \mu \mathrm{m})$ fractions. The size distribution of the mud fraction was determined using a Sedigraph $5100 \mathrm{X}$-ray particle size analyzer to provide the weight percent of clay $(<3.9 \mu \mathrm{m})$ and silt $(>3.9<63 \mu \mathrm{m})$ components (see Appendix). In addition, Sedigraph size analysis provided data to determine weight percent of coarse silt $(>31 \mu \mathrm{m})$ for distinguishing between mudstones and wackestones (Fig. 3). The sand and gravel fraction was dry-sieved into $>63,>125-<250,>250-<500$, and $>500 \mu \mathrm{m}$ subfractions. Each subfraction was examined under a binocular microscope to determine sediment composition and also to estimate the percentage of cemented aggregates and authigenic pyrite. These components were deducted from the weight percent of each subfraction, so that the grain-size distribution data presented in the Appendix reflect original grain-size variation as closely as possible. Note that significant proportions of cemented aggregates exist from $100 \mathrm{mbsf}$ downward (see below), and that grain-size analyses would have been meaningless without the removal of cemented aggregates from these calculations.

Calcium carbonate determinations (see Appendix) were made on $1 \mathrm{~g}$ of the archive half of each sample using a pressure bomb technique (Müller and Gastner, 1971). Hydrochloric acid (usually $20 \mathrm{~mL}$ ) was added to each sample until the sample was fully dissolved, and the pressure of evolved $\mathrm{CO}_{2}$ gas measured. The gas pressure was converted to percentage of $\mathrm{CaCO}_{3}$ using calibration curves determined from pure carbonate samples for each bomb. Calcium carbonate analyses from Site 820 samples performed on board the JOIDES Resolution during the drilling leg were also included in the $\mathrm{CaCO}_{3}$ data, after it was first established that any systematic difference resulting from the use of two different analytical methods was negligible (less than $2 \%$ ).

\section{Downhole Logging}

Following completion of coring of Hole $820 \mathrm{~B}$, the drill pipe was pulled to approximately $75 \mathrm{mbsf}$ and four logging strings were sequentially deployed (Davies, McKenzie, Palmer-Julson, et al., 1991); a geophysical tool string (sonic, spectral gamma-ray, high-temperature lithodensity, phasor resistivity, mechanical caliper, and temperature tools); a geochemical tool string (aluminum clay, gamma spectroscopy, spectral gamma-ray, and temperature tools); a formation microscanner tool string (formation microscanner [FMS], spectral gamma-ray, inclinometer, and temperature tools); and a vertical seismic profile tool. Although the reprocessed geochemical logs (see Pratson et al., this volume) include measurements taken through the pipe in the top $75 \mathrm{~m}$ of the hole, these measurements are considerably more noisy and less reliable than open-hole measurements. Note that gamma-ray and neutron porosity logs (Fig. 4) were processed post-cruise to compensate for borehole size variations.

\section{DOWNHOLE LOG RESULTS}

Downhole logs from Site 820 provide continuous records of changes in geochemistry and physical properties with depth. We used the reprocessed geochemical logs of Pratson et al. (this volume), as well as the edited velocity and density logs of Jarrard et al. (this volume). Geochemical logs are most reliable, and velocity and density logs were obtainable only in the open-hole interval below about 75 mbsf. Therefore, Jarrard et al. (this volume) merged the open-hole logs with shallower measurements of velocity and density from cores to obtain continuous records that extend from the seafloor to near the bottom of the hole.

Log responses at Site 820 are dominated by variations in relative abundance of the two major sedimentary components: carbonate (low$\mathrm{Mg}$ calcite, high-Mg calcite, dolomite, and aragonite) and clay minerals (principally smectite, kaolinite, and illite; Chamley et al., this volume). Quartz is subsidiary, with an abundance of only $5 \%$ to $26 \%$ (Davies, McKenzie, Palmer-Julson, et al., 1991). In this essentially two-component system, the calcium geochemical log was expected to be positively correlated with carbonate content. In contrast, the $\mathrm{K}_{2} \mathrm{O}$ and $\mathrm{Al}_{2} \mathrm{O}_{3}$ logs were expected to be inversely correlated with carbonate, because nearly all the potassium and aluminum are in clay minerals. At depths of less than 1 to $2 \mathrm{~km}$, compaction has not yet established a strongly preferred orientation among platy clay minerals. Thus, clay-rich sediments have much higher porosity than do carbonates (e.g., Hamilton, 1979). Consequently, velocity and density were expected to be positively correlated with carbonate content, at least over short distances.

Comparison of calcium carbonate content determinations from individual samples with the calcium log provided by the geochemical tool string (Fig. 5) shows that the downhole tool provides a reasonably good approximation of carbonate content when measuring through 


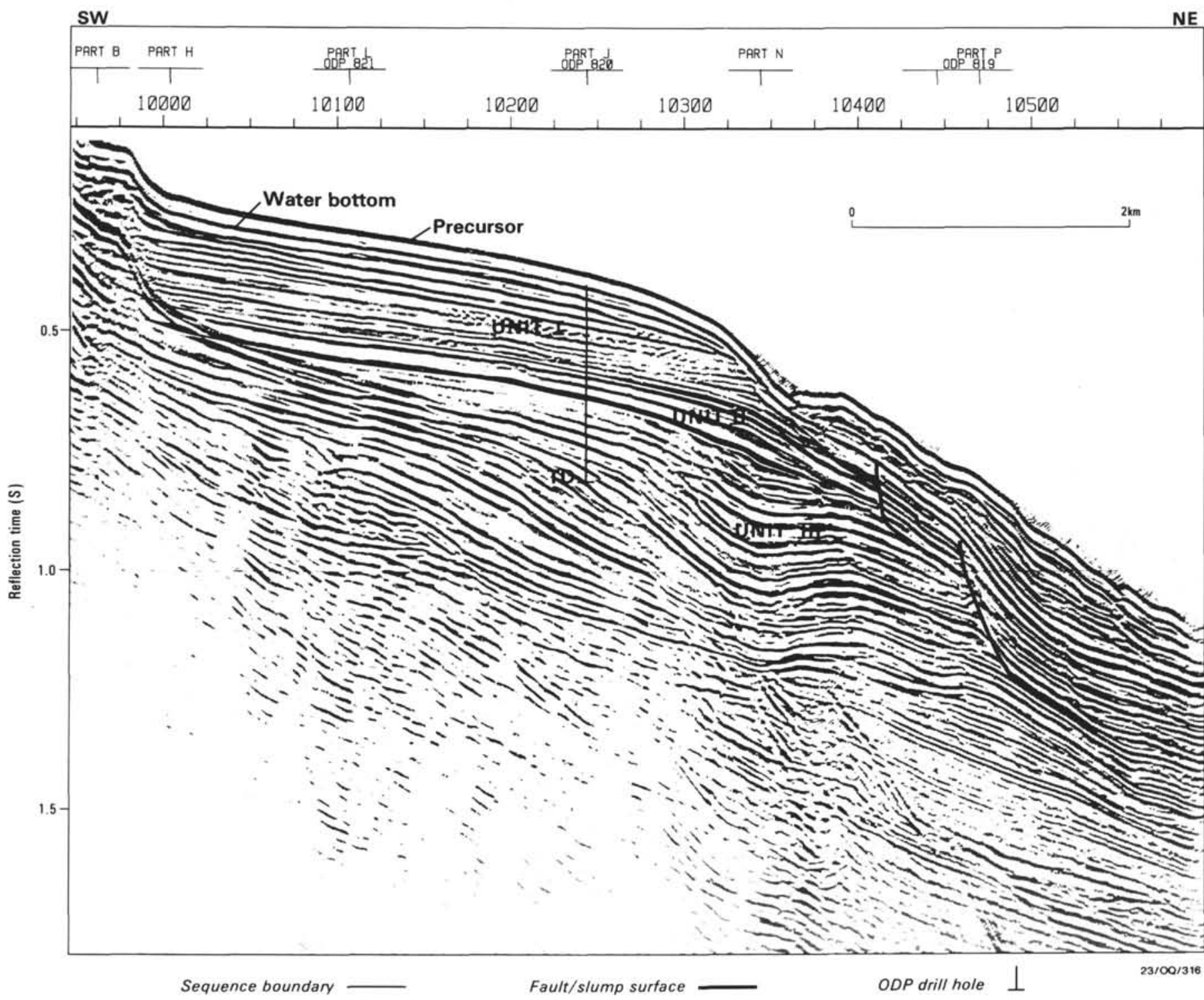

Figure 2. Seismic section across the central Great Barrier Reef outermost slope/upper shelf (BMR line 75/43T) showing lithological units intersected at Site 820. Location of seismic line is shown in Figure 1.

the drill pipe in the uppermost $75 \mathrm{~m}$ of the hole, and an excellent indication of carbonate content in the open hole below 75 mbsf. Because of the relatively close spacing (approximately $15 \mathrm{~cm}$ ) of downhole measurements, the calcium log provides a better indication of carbonate variations in the open hole than the more widely spaced carbonate determinations from samples.

The suite of downhole logs presented here (Figs. 4 and 5) provide a clear indication of the close correlation between log characteristics and sediment compositional and textural variabilities. The log characteristics of individual lithologic units are described within the lithofacies descriptions (see below). The boundaries between lithologic units and subunits can be reliably identified within cores where core recovery was high; however, in zones of poor or no recovery, downhole logs provide more precise estimations of the locations of the lithologic boundaries (Figs. 3 and 4).

\section{LITHOFACIES}

Lithologies recovered at Site 820 consist almost exclusively of greenish-gray to dark greenish-gray wackestones interbedded with coarser, greenish-gray, bioclastic packstones (Davies, McKenzie,
Palmer-Julson, et al., 1991). Subtle variations in textural and compositional characteristics permit the identification of three lithologic units. Unit I ( $0-146 \mathrm{mbsf})$ consists of bioclastic fine wackestone interbedded with bioclastic coarse wackestone and packstone horizons. Unit II (146-208 mbsf) is a transitional unit that consists of coarsening-upward sequences of bioclastic, clayey fine wackestone grading up to very fine to fine sand-sized bioclastic wackestone/packstone. Unit III (208-400 mbsf) consists of seven coarsening-upward cycles (or subunits), characterized by transitions from bioclastic fine wackestone up to very fine to fine sand-sized bioclastic wackestone/packstone. The fundamental difference between Units II and III, characterized by coarsening-upward grain-size trends, and Unit I, lacking such obvious cyclicity but displaying episodic alternations between coarser and finer intervals, is illustrated schematically in Figure 3. In Figures 6 and 7, we present grain-size distribution and carbonate content variation data for Site 820 samples.

\section{Unit I}

Unit I is dominated by bioclastic fine wackestone, with subsidiary interbedded bioclastic coarse wackestone/packstone horizons. The 


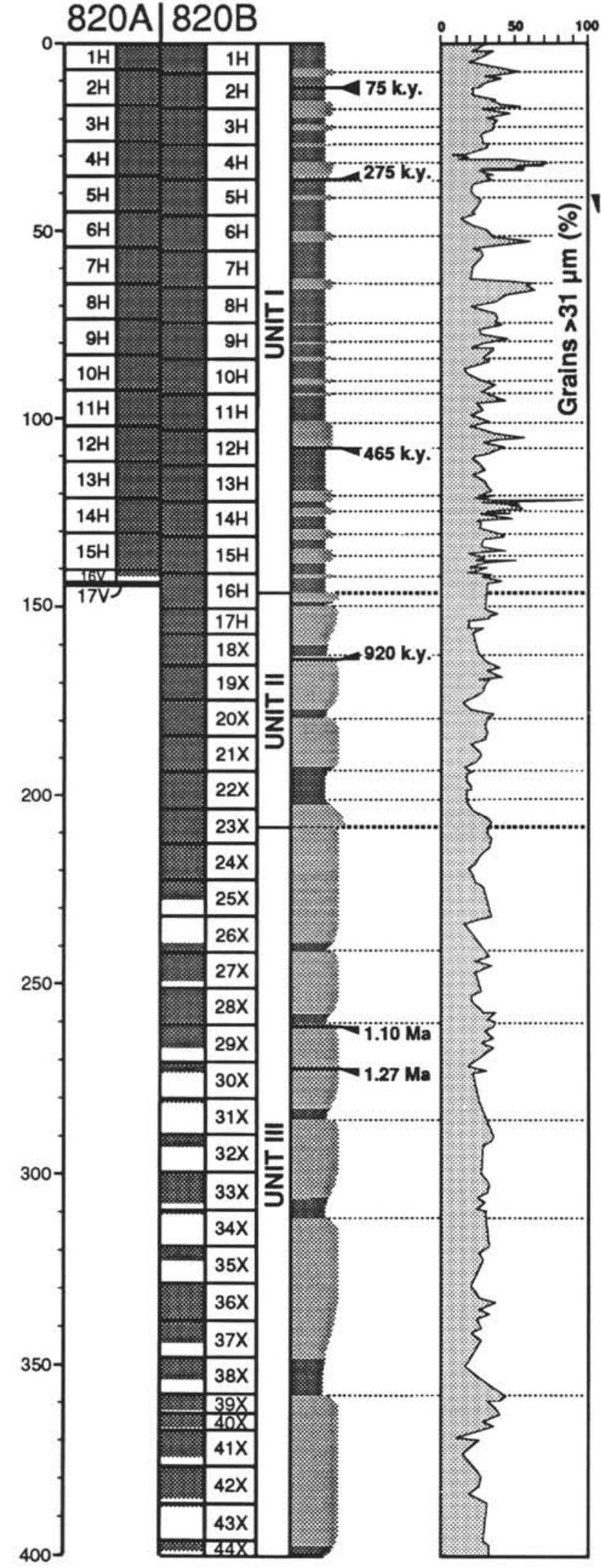

Figure 3. Lithofacies summary, nannofossil datums, and core recovery at Site 820; grain-size variation is shown schematically, with coarser lithologies represented by increased column width. The proportion of coarse silt- and sand-sized detritus $(>31 \mu \mathrm{m})$ also is shown. Nannofossil datums are after Wei and Gartner (this volume). Individual hydraulic piston cores are labeled $1 \mathrm{H}$, $2 \mathrm{H}$, and so forth; $16 \mathrm{~V}$ and $17 \mathrm{~V}$ are vibrapercussive cores; and extended core barrel cores are labeled 18X, 19X, and so forth. unit extends from the sediment surface to $146 \mathrm{mbsf}$, where there is a transition into the coarsening-upward cycles which are characteristic of Unit II. This transition can be correlated with a prominent erosional unconformity and sequence boundary on seismic sections (Fig. 2). Unit I corresponds with the entire aggradational package that forms the Great Barrier Reef outer shelf (Feary, Symonds, et al., this volume), overlying sequences characterized by progradational seismic geometries.

The coarse wackestone/packstone horizons make up $28 \%$ of Unit I, occurring in 19 beds that range from 0.3 to $7 \mathrm{~m}$ thick (Fig. 3). Bioturbation mottling is pervasive throughout the entire unit, which tends to "blur" bed boundaries. Burrows within the finer-grained portions of the unit are commonly filled with coarser-grained foraminifers and bioclasts. The grain-size difference between coarser and finer portions of Unit I is considerably greater than in underlying units (Fig. 6). The coarser horizons within Unit I contain significant fine, medium, and coarse to very coarse sand-sized components, with three of the coarse horizons containing more than $10 \%$ in the $>500 \mu \mathrm{m}$ fraction (Fig. 6). The finer-grained wackestone horizons contain $<15 \%$ sandsized material $(>63 \mu \mathrm{m})$.

In general, carbonate content values within the lower half of Unit I are uniformly high $(>50 \%)$, whereas values within the upper half of the unit show much greater variation, ranging from $30 \%$ to $80 \%$ (Fig. 7). Compositional variation throughout Unit I does not show the marked correlation with textural variation that characterizes underlying units. Coarser-grained horizons do have the highest carbonate content values (mostly $>70 \%$ ); however, finer wackestone horizons show a wide range of $\mathrm{CaCO}_{3}$ values (Fig. 7). Finer horizons in the lower half of Unit $\mathrm{I}$ have $\mathrm{CaCO}_{3}$ contents consistently greater than $60 \%$, close to those of the interbedded coarser horizons, whereas finer intervals within the upper half of the unit have $\mathrm{CaCO}_{3}$ contents that range from $<40 \%$ to $>60 \%$. The higher carbonate content values within the lower half of the unit are partly a result of the presence of aggregates formed by authigenic calcite cementation (Fig. 7).

No consistent cyclicity is apparent throughout Unit I, although there do appear to be repeated coarsening-upward trends within the uppermost 50 to $60 \mathrm{~m}$ of the sequence $(7-12,17-31,36-50$, and $51-63 \mathrm{mbsf}$ ). These trends correspond to increasing carbonate content values. The transitions between cycles are marked by abruptly decreased grain-size and $\mathrm{CaCO}_{3}$ content values (Figs. 6 and 7). However, a much closer sample spacing (e.g., Peerdeman and Davies, this volume) would be necessary to describe this cyclicity completely.

Bioclastic constituents throughout Unit I are dominated by planktonic foraminifers, with coarse fractions $(>125 \mu \mathrm{m})$ also containing abundant benthic foraminifers, molluscan and pteropod fragments, indeterminate bioclastic fragments and spines, together with minor echinoid, coral, coralline algal, and bryozoan fragments (Fig. 8). The proportion of indeterminate bioclastic material is greater in finer fractions. The coarse wackestone/packstone beds at 7 and $32 \mathrm{mbsf}$ (Fig. 3) also contain significant proportions of rhodoliths and lithoclasts (Fig. 9), and the thick, coarse-grained packstone/floatstone at 124 mbsf contains abundant Halimeda fragments. Terrigenous material is present throughout the unit as clay and as silt- and very fine sand-sized quartz and feldspar grains.

In contrast to underlying units, downhole logs reflect the textural and compositional variability throughout Unit I poorly. Of the geophysical logs (Fig. 4), only the corrected density log reflects the grain-size and carbonate content cyclicity that occurs within the uppermost $60 \mathrm{~m}$. The geochemical logs (Fig. 5) better reflect broad compositional and textural variability, although the influence of the drill pipe in the top $75 \mathrm{~m}$ has introduced additional "noise" into the $\log$ signal. However, the generally high $\mathrm{CaCO}_{3}$ values from core samples in the lower half of Unit I are reflected in consistently high values in the $\mathrm{CaCO}_{3} \log$ and low values in the $\mathrm{SiO}_{2} \log$. The coarsergrained horizons within the lower part of the unit are also predictably reflected in low values on the $\mathrm{K}_{2} \mathrm{O}$ and $\mathrm{Al}_{2} \mathrm{O}_{3}$ logs. 


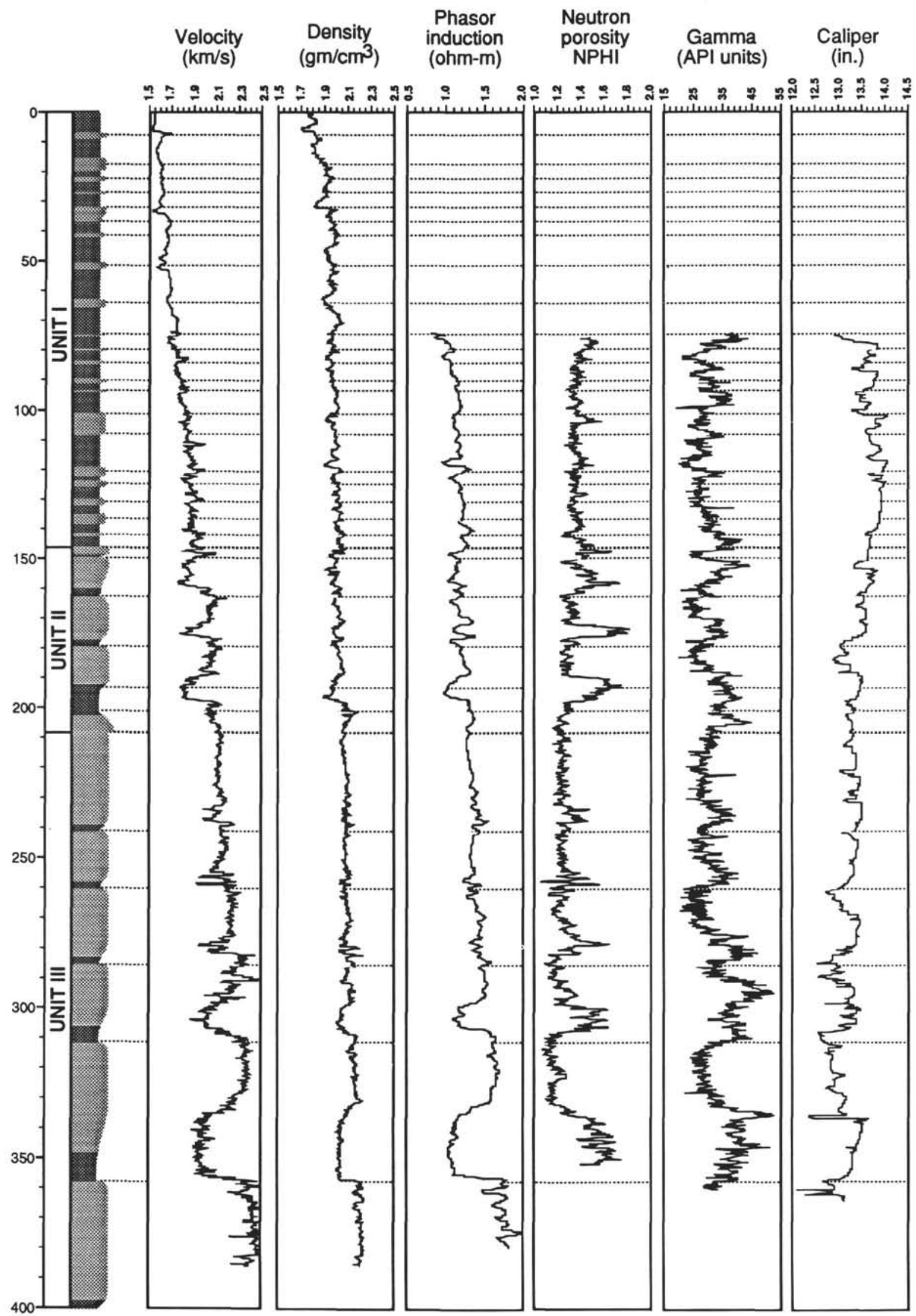

Figure 4. Selected downhole logs from the geophysical tool string. The schematic summary on the left (from Fig. 3) shows the corresponding lithofacies variation and unit boundaries. 


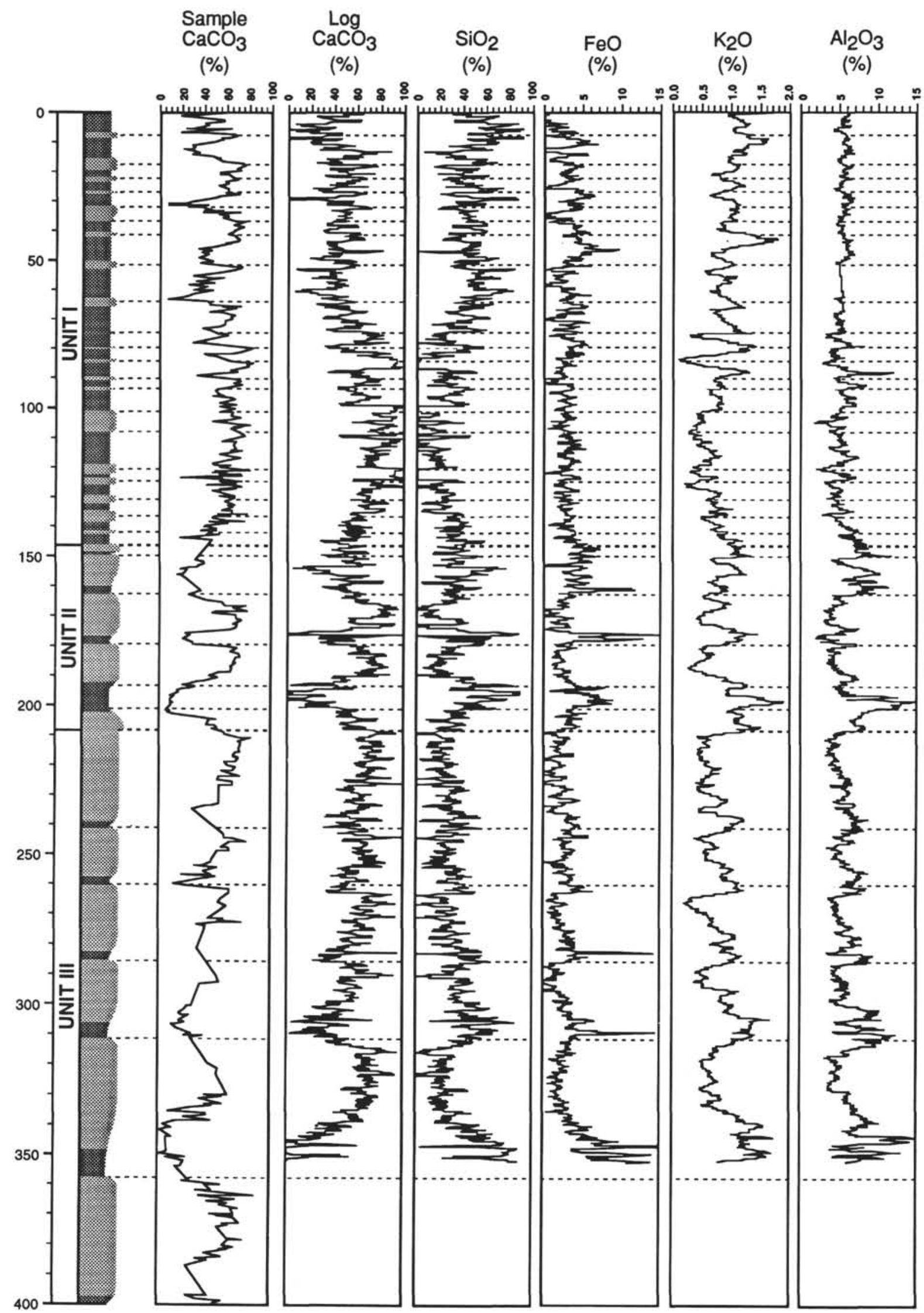

Figure 5. Selected downhole logs from the geochemical tool string (after Pratson et al., this volume). The schematic summary on the left (from Fig. 3) shows the corresponding lithofacies variation and unit boundaries. The $\mathrm{CaCO}_{3}$ percentages derived from onboard and laboratory sample analyses, shown next to the $\mathrm{CaCO}_{3}$ downhole $\log$ for comparison, are from Figure 7 . 


\section{Cumulative} grain-size

(\%)
Schematic summary
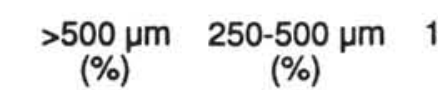

(\%)

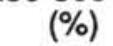

(1)

(\%)

$\%)$

63-125 $\mu \mathrm{m}$

(\%)

$3.9-63 \mu \mathrm{m}$

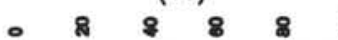

० 8 8 8 \&
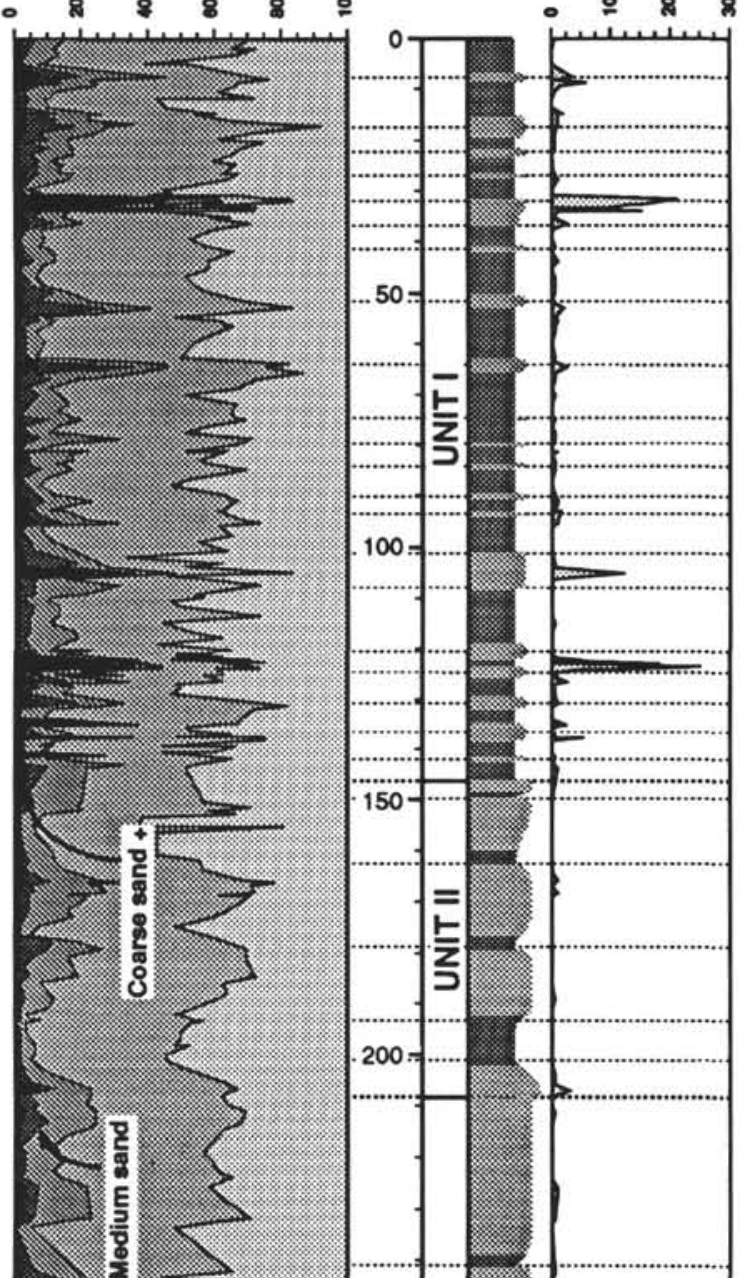

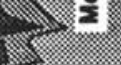

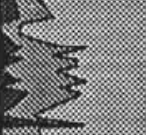

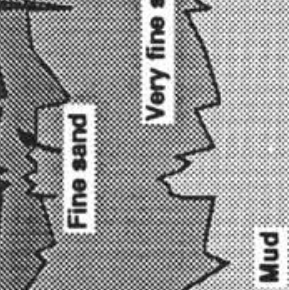
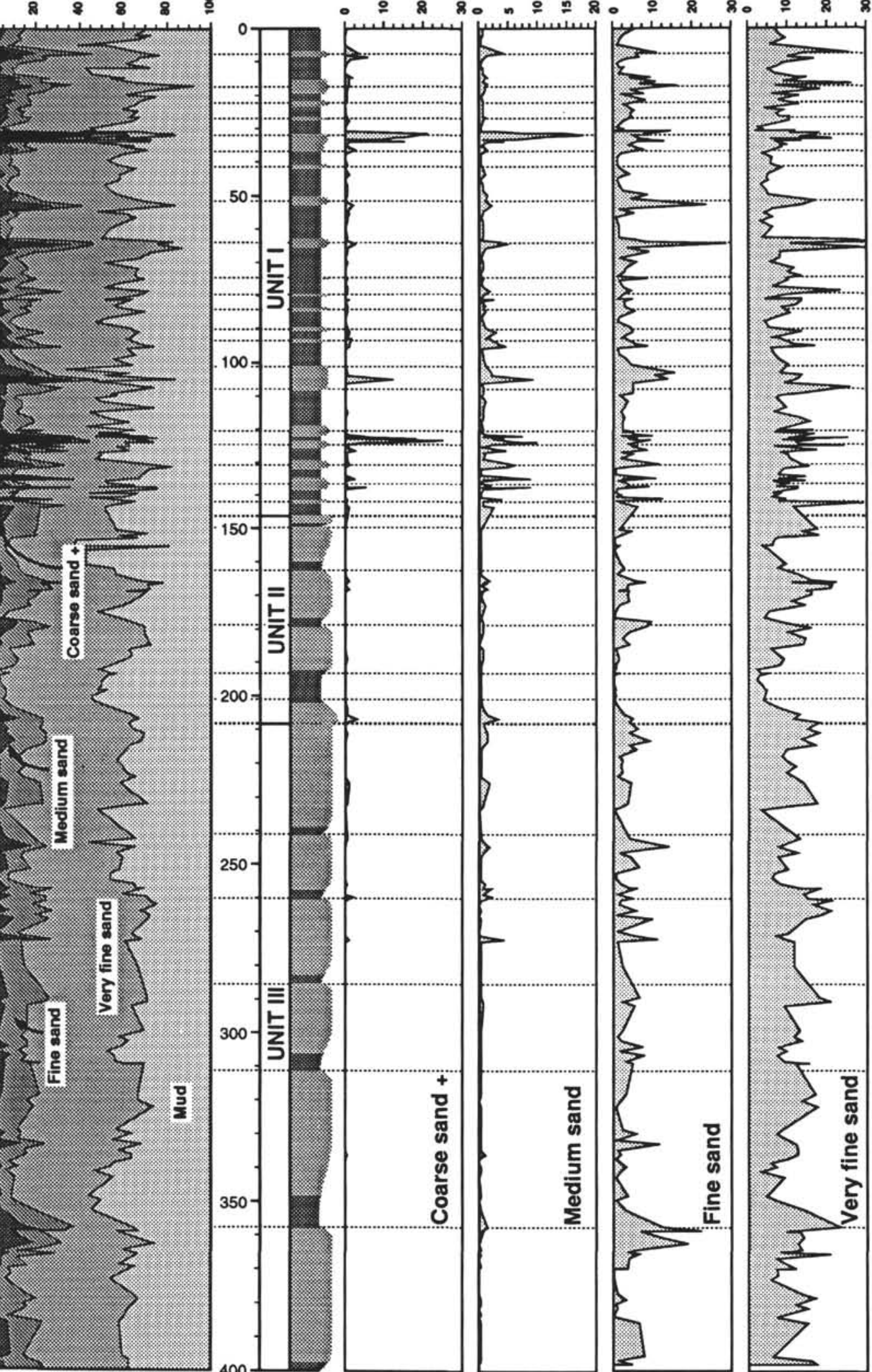

(\%)

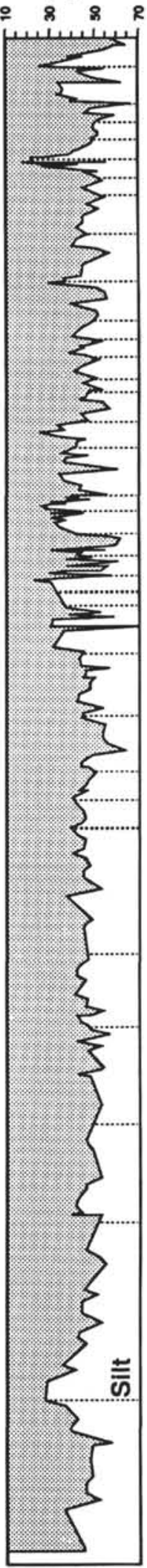

Figure 6. Grain-size distribution (see the Appendix) throughout Site 820. The schematic summary (from Fig. 3) shows the corresponding lithofacies variation and unit boundaries. The graphs on the right show proportions of individual size fractions, whereas the diagram on the left shows cumulative size fraction proportions. 


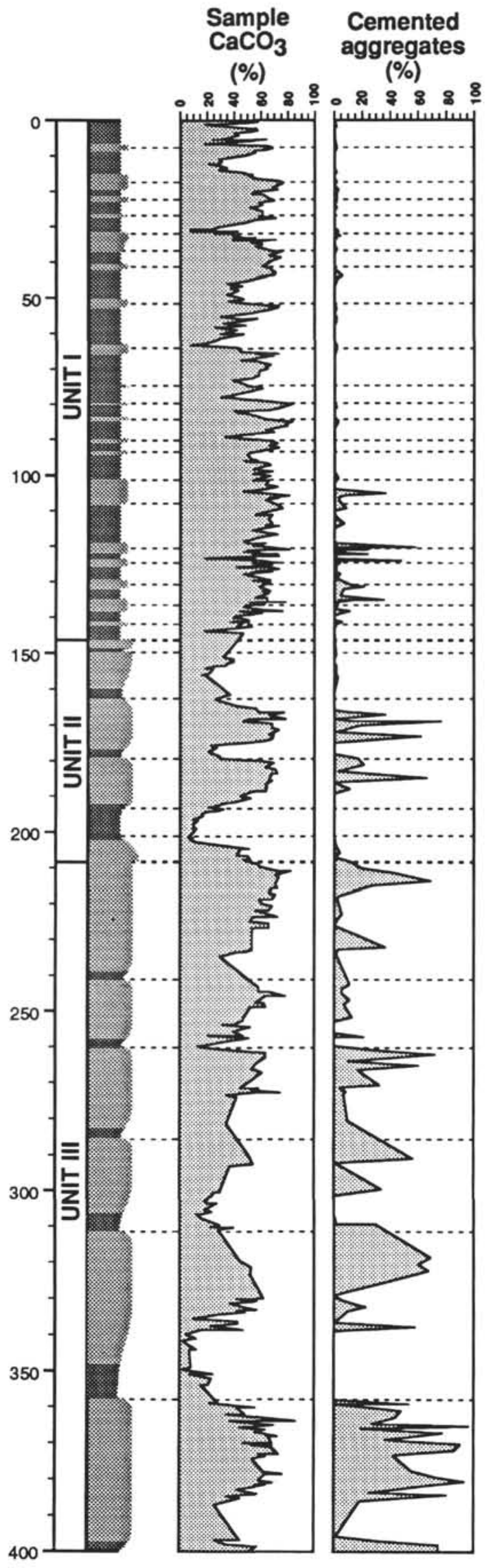

Figure 7. Calcium carbonate content for Site 820. Data include post-cruise sample analyses (see the Appendix), merged with analyses performed during the cruise (Davies, McKenzie, Palmer-Julson, et al., 1991). The schematic summary is from Figure 3.

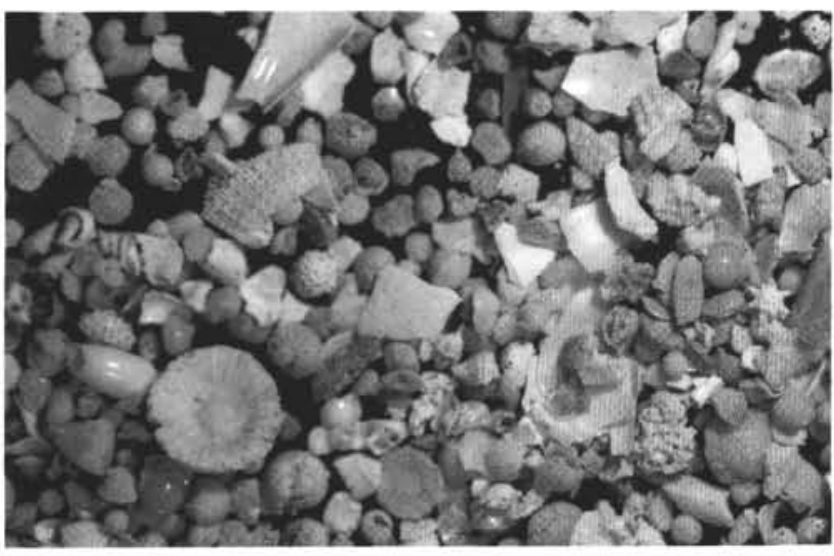

Figure 8. Photograph showing representative coarse fraction $(>5 \overline{00 \mu \mathrm{m}) \text { grain }}$ population from Unit I; the dominant constituents are planktonic foraminifers and indeterminate bioclastic fragments, together with benthic foraminifers and coral, echinoid, and mollusk fragments (138 mbsf; Sample 133-820A-15H-5, $137-139 \mathrm{~cm}$ ). Scale bar $=2 \mathrm{~mm}$.

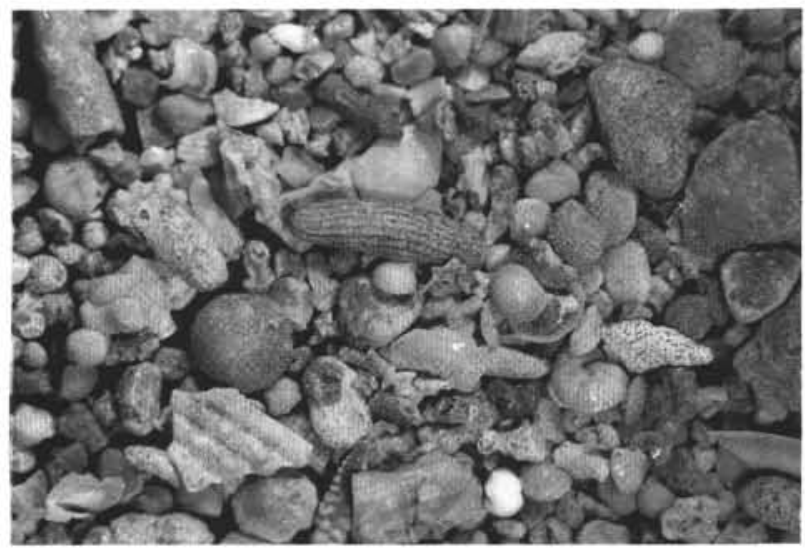

Figure 9. Photograph showing representative coarse fraction $(>5 \overline{00 \mu \mathrm{m}) \text { grain }}$ populations from the coarsest bed within Unit I. Note the large, rounded lithoclasts and abundant bioclastic debris (32 mbsf; Sample 133-820B-4H-4, $20-22 \mathrm{~cm}$ ). Scale bar $=2 \mathrm{~mm}$.

The three nannofossil datums occurring within Unit I (75 k.y. at $12.1 \mathrm{mbsf} ; 275$ k.y. at $35.8 \mathrm{mbsf}$; and 465 k.y. at $107.8 \mathrm{mbsf}$; see Wei and Gartner, this volume) provide reasonably good biostratigraphic age control. Although the occurrence of the 920 k.y. datum toward the top of Unit II provides additional age constraint, the boundary between the two units is a pronounced unconformity, implying significant missing time (Feary, Symonds, et al., this volume). Accordingly, it is difficult to estimate sediment accumulation rates and the age at the base of the unit. Considerable variability exists in sediment accumulation rates between the nannofossil datums occurring within Unit I (ranging from $38 \mathrm{~cm} / \mathrm{k} . \mathrm{y}$. between the 275 and $465 \mathrm{k} . \mathrm{y}$. datums to $12 \mathrm{~cm} / \mathrm{k} . \mathrm{y}$. between the 75 and 275 k.y. datums, with $16 \mathrm{~cm} / \mathrm{k}$.y. at the top of the unit). Evidence from seismic data of debris flow deposition between 36 and 70 mbsf (Feary, Symonds, et al., this volume) implies that the increased sediment accumulation rate between 36 and 107.8 mbsf may have resulted from this process. Accordingly, an average accumulation rate of approximately $13 \mathrm{~cm} / \mathrm{k}$.y. at the base of the unit has been used to estimate an age of $760 \mathrm{k} . \mathrm{y}$. at the unit boundary.

\section{Unit II}

Unit II consists of a mixture of relatively coarse bioclastic packstone; finer, clayey, bioclastic wackestone; and fine-grained, silty 
wackestone. This unit represents a transition between the thicker, coarsening-upward cycles of Unit III and the wackestones with discrete interbedded packstone horizons of Unit I. The base of Unit II is marked by an abrupt coarsening, from uniform packstones at the top of the uppermost coarsening-upward cycle in Unit III to the base of a fining-upward sequence containing coarse sand-sized bioclastic detritus. This boundary corresponds with a pronounced erosional unconformity in seismic sections (Fig. 2; see Feary, Symonds, et al., this volume).

The 3-m-thick fining-upward interval (205-208 mbsf) that forms the base of Unit II passes upward into a 9-m-thick, uniformly finegrained wackestone interval (197-205 mbsf) that contains negligible sand-sized detritus (Fig. 6). This is, in turn, overlain by four coarsening-upward cycles (179-197 mbsf; 161-179 mbsf; 151-161 mbsf; and 146-151 mbsf) that become progressively thinner, and with less well-defined grain-size gradation, toward the top of the unit. In each case, cycles grade from fine-grained (silt-sized) wackestones at the base, up into coarser (silt- to fine sand-sized) wackestones to packstones at the top. Minor bioturbation occurs throughout the finergrained parts of this unit, with many burrows filled in with medium to coarse sand-sized grains, predominantly foraminifers and bioclasts.

A close correspondence is seen between compositional and textural parameters, with coarser-grained portions of Unit II having higher carbonate contents (up to $70 \%-80 \%$ ) compared with finergrained portions ( $<40 \%$ ) (Fig. 6; Appendix). Compositional gradations within the central part of Unit II are even more pronounced than textural gradations, as a consequence of authigenic calcite formation that produced abundant cemented aggregates within coarser parts of the lower two coarsening-upward cycles (Fig. 6). Although the bioclastic content varies with carbonate content throughout the unit, the bioclastic constituents show much less variation. Foraminifers dominate in coarser fractions $(>250 \mu \mathrm{m})$, together with abundant bioclasts of indeterminate origin and minor mollusk, ostracode, and coral fragments (Fig. 10). Pteropods form a significant proportion of coarse fractions toward the base of each cycle. Finer fractions $(<250 \mu \mathrm{m})$ also contain abundant foraminifers, but in addition contain large quantities of bioclasts of indeterminate origin.

The finer-grained, less calcareous portions of Unit II, particularly the thick, finer interval toward the base of the unit (197-205 mbsf), have distinctive signatures in downhole logs (Figs. 4 and 5), represented by low values in velocity, induction, density, and $\mathrm{CaCO}_{3} \operatorname{logs}$, and by high values in gamma, $\mathrm{SiO}_{2}, \mathrm{FeO}, \mathrm{K}_{2} \mathrm{O}$, and $\mathrm{Al}_{2} \mathrm{O}_{3}$ logs. In contrast, grain-size and carbonate gradations within coarser-grained, more calcareous intervals are less obvious in most logs, although the three coarsening-upward cycles that comprise the bulk of the unit (151-197 mbsf) are clearly represented by increasing values in the velocity and $\mathrm{CaCO}_{3}$ logs. This close correspondence between the velocity $\log$ and the linked grain-size/carbonate content gradations is a consequence of greater cementation within the coarser zones (see proportion of cemented aggregates in Fig. 7) that produced increased sonic velocities.

Biostratigraphic data show that the 920-k.y. nannofossil datum occurs toward the top of Unit II (Fig. 3); however, the next oldest datum, at $1.1 \mathrm{~m} . y$., is well below the base of the unit (Wei and Gartner, this volume). Therefore, we were only able to estimate Unit II duration by assuming approximately constant sedimentation rates between datums; a questionable assumption, considering the time loss associated with the sequence boundary unconformities and onlap surfaces at the base of Unit II and within Unit III (Feary, Symonds, et al., this volume). Such a calculation provides a crude estimate for Unit II age of 0.760 to 1.015 m.y., and an average sedimentation rate at Site 820 of $24 \mathrm{~cm} / \mathrm{k} . \mathrm{y}$. However, Site 820 is located on what was the margin of a submarine valley during Unit II sedimentation (Feary, Symonds, et al., this volume), and the depocenter at this time lay about $2 \mathrm{~km}$ toward the southeast. The average sedimentation rate for Unit II at the depocenter was approximately $60 \mathrm{~cm} / \mathrm{k} . \mathrm{y}$.

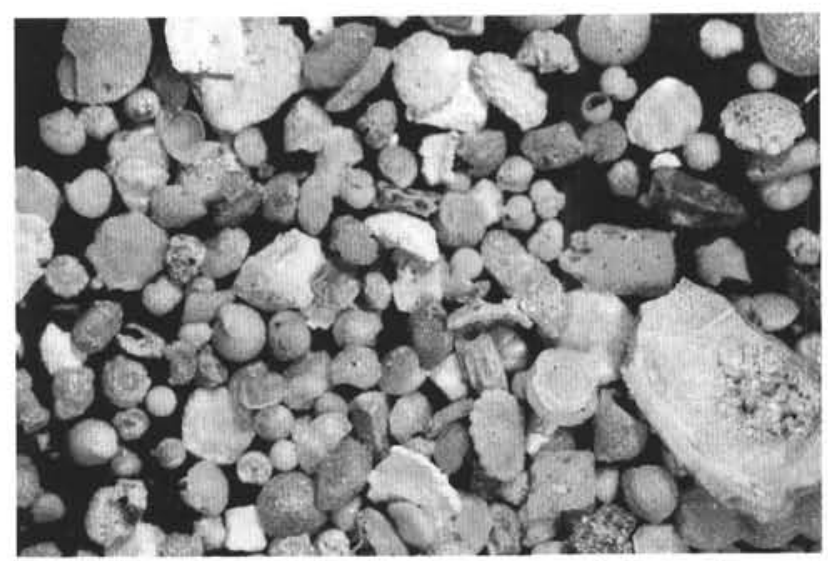

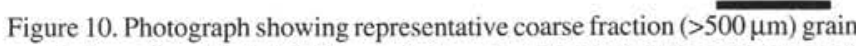
populations from Unit II (207 mbsf; Sample 133-820B-23X-3, 75-77 cm). Scale $b a r=2 \mathrm{~mm}$.

\section{Unit III}

Unit III is dominated by dark greenish-gray, relatively coarse bioclastic wackestone and packstone, with thin intervals of fine bioclastic wackestone. The juxtaposition of finer and coarser lithologies defines a coarsening-upward cyclicity which is the major lithologic characteristic of the unit. Seismic data (Fig. 2) show that the Unit III interval intersected at Site 820 is the uppermost part of a thick succession characterized by prograding clinoforms (Feary, Symonds, this volume), and accordingly it is likely that similar coarseningupward lithological cycles extend much deeper into the sediment pile.

Although coarsening-upward cyclicity is the dominant lithological characteristic of this unit, it is nevertheless a subtle feature. A substantial proportion $(60 \%-70 \%)$ of clay and very fine to medium silt-sized material ( $<31 \mu \mathrm{m}$; see Fig. 3) occur within coarser parts of each cycle. Similarly, a significant proportion (10\%-20\%) of coarser detritus occurs within finer portions of each cycle, typically forming thin $(2-4 \mathrm{~cm})$ foraminifer bioclast packstone beds. The grain-size variation within each cycle therefore is a slight variation in the relative proportions of mud- and sand-sized components. The cyclicity is best displayed by comparing variations in clay content with coarser material (Fig. 6). The top of each cycle is marked by a relatively thin fining-upward interval. The six coarsening-upward cycles that comprise this unit range from 22 to $48 \mathrm{~m}$ thick, with no discernible overall grain-size or cycle thickness trends within the unit.

Bioturbation mottling occurs throughout Unit III, in some cases completely disrupting thinner beds. This is particularly obvious where thin coarser beds occur within the finer portions of each cycle. Despite the pervasive bioturbation mottling, ubiquitous lamination occurs as thin, darker "wisps" within the coarser packstone beds, and as more continuous horizontal lamination within finer beds. One example of cross lamination occurs at 342 mbsf.

As is the case with Unit II, textural cyclicity within Unit III is matched by an even more pronounced carbonate content cyclicity (Fig. 7). Carbonate contents vary from maxima of $60 \%$ to $80 \%$ within coarser parts of each cycle, to $<50 \%$ within finer parts. However a slight difference exists between the textural and compositional cyclicities, with much thicker intervals of upward-decreasing $\mathrm{CaCO}_{3}$ values compared with the corresponding fining-upward intervals. This results in the $\mathrm{CaCO}_{3}$ peaks occurring toward the middle of the coarsening- upward cycles, particularly in the lower parts of Unit III (Figs. 6 and 7). The proportion of aggregates formed by authigenic calcite cementation increases downhole (Fig. 7), with the highest $\mathrm{CaCO}_{3}$ contents within each cycle corresponding to the highest proportions of cemented aggregates. The proportion of aggregates within the lower cycles of Unit III are sufficiently high to give the lithology 
a pronounced "chalky" appearance. In some cases, the presence of cemented aggregates within the coarsest parts of each cycle has produced slight distortion of grain-size graphs (Fig. 6), as a consequence of the aggregate component being discounted during particle size analysis (see above).

The composition of grains within Unit III is essentially identical to that of Unit II, with the only difference being a decreased coral fragment component. Foraminifers dominate in coarser fractions $(>250 \mu \mathrm{m}$ ), and are particularly important (at the expense of the proportion of indeterminate bioclast fragments) at the top of coarsening-upward cycles. In addition to abundant indeterminate bioclasts, there are minor proportions of molluscan and ostracod fragments. As is the case in Unit II, pteropods form a significant proportion of coarse fractions toward the base of each cycle. Finer fractions $(<250 \mu \mathrm{m})$ also contain abundant foraminifers, but in addition contain large quantities of indeterminate bioclasts. Quartz is present in trace quantities in many samples from coarser parts of cycles, and is present as silt-sized particles within most fine fraction samples.

Unit III textural and compositional cyclicity is reflected on both geophysical and geochemical downhole logs (Figs. 4 and 5). Cyclicity is particularly obvious on the velocity log, reflecting increased velocities within the coarser, more calcareous cemented zones. The phasor induction log similarly shows a clear cyclicity. The density log indicates generally lower and more variable values within finergrained intervals, which also yield higher neutron porosity values. The $\mathrm{Al}_{2} \mathrm{O}_{3}, \mathrm{~K}_{2} \mathrm{O}, \mathrm{FeO}$, and $\mathrm{SiO}_{2}$ geochemical logs show increased values within the finer intervals, with the $\mathrm{CaCO}_{3} \log$ predictably showing decreased values. The coarsening-upward trends are particularly clear in the $\mathrm{K}_{2} \mathrm{O}$ and $\mathrm{CaCO}_{3}$ logs.

Nannofossil data show that the $1.10 \mathrm{Ma}(260.26 \mathrm{mbsf})$ and $1.27 \mathrm{Ma}$ (271.65 mbsf) datums occur within Unit III (Fig. 3) and that the next oldest datum (1.48 Ma) is not intersected at this site (Wei and Gartner, this volume). Accordingly, it was not possible to determine accurately either the age range or sedimentation rate for this unit. However, it was possible to estimate an age of approximately $1.015 \mathrm{Ma}$ for the top of the unit, assuming a broadly constant sedimentation rate. Accordingly, the minimum average sedimentation rate for Unit III is $41 \mathrm{~cm} / \mathrm{k} . \mathrm{y}$ at Site 820 . This corresponds to $143 \mathrm{~cm} / \mathrm{k} . \mathrm{y}$. at the Unit III depocenter, which lies some $2 \mathrm{~km}$ to the southeast within a broad submarine valley (Feary, Symonds, et al., this volume).

\section{DISCUSSION AND CONCLUSIONS}

Despite an overall lithological uniformity throughout the sequence cored at Site 820, textural and compositional analyses demonstrate that the Pleistocene uppermost slope to outermost shelf succession was deposited in two distinctively different sedimentation styles. The coarsening-upward and carbonate content cyclicity characteristic of Unit III, clearly visible in downhole logs, is completely different from the finer lithofacies with coarse interbeds that dominate Unit I. Unit II lithofacies represent a transitional sedimentation style. These different lithological units exactly correspond to markedly different seismic sequence geometries identified from high-resolution site survey seismic data (Feary et al., 1990; Feary, Symonds, et al., this volume). Lithological Unit I corresponds to sequences characterized by aggradational geometry (seismic sequences 1-3 of Feary, Symonds, et al., this volume); lithological Unit III to sequences characterized by sigmoidal progradational geometry (seismic sequences 5-9 of Feary, Symonds, et al., this volume); and lithological Unit II corresponds to a seismic sequence (seismic sequence 4 of Feary, Symonds, et al., this volume) possessing both aggradational and progradational characteristics. Together with textural and compositional parameters, seismic facies characteristics therefore are an important element for understanding the sedimentary processes and controls for each unit.

Seismic data show that the sigmoidal progradational package (Unit III) represents rapid sedimentation within upper slope submarine valleys, with deposition controlled by base-level variations
(Feary, Symonds, et al., this volume). Cyclic alternation of sediment onlap and drape are repeated throughout the progradational package. Onlap represents a relative lowering of depositional base-level (Vail et al., 1977), which caused the locus of sedimentation to step off the paleoshelf edge and down into the submarine valley system, whereas drape represents a relative rise in depositional base-level, which permitted sediment to be deposited more evenly over the entire outer shelf and upper slope. Sediment was not point-sourced within the region of the seismic grid, but rather was supplied around the valley margins. The concentration of sediment on the southern side of the valley margins for a number of the progradational sequences indicates that reworking of shelf sediment into the valleys was at least partly the result of currents from the south (Feary, Symonds, et al., this volume).

Paleodepth estimates from benthic foraminifer studies (Davies, McKenzie, Palmer-Julson, et al., 1991) provide a key element for correlating the cyclic deposition, represented by the multiple coarsening-upward cycles characteristic of the progradational sequences, with the base-level variations indicated by seismic stratal relationships. Paleodepth determinations show that Site 820 faunas consistently indicate upper bathyal $(200-600 \mathrm{~m})$ paleodepths in lower parts of the coarsening-upward cycles, and outer neritic $(100-200 \mathrm{~m})$ paleodepths in higher parts of the cycles (Davies, McKenzie, PalmerJulson, et al., 1991). The coarsening-upward cycles therefore indicate repeated shallowing-upward, regressive cycles, with the thin, finingupward tops to each cycle representing deepening. Accordingly, it is possible to infer the relationship between this regressive cyclicity and lithofacies characteristics for each component of depositional baselevel variation as follows:

1. Sea-level rise: produced a relatively condensed, muddy sequence, with coarse bioclastic material either not produced on the inner shelf, or trapped there; the mud component was the "background" sediment deposited during all stages.

2. Sea-level highstand: produced the rapidly coarsening part of each cycle, as the coarse bioclastic material that was produced on the shelf during this and the rising base-level stage could be moved offshore by shelf currents and storms.

3. Sea-level fall: led to continued deposition of both coarse and fine detritus, with a higher sedimentation rate as drainage systems attempted to maintain equilibrium.

4. Sea-level lowstand: produced continued deposition of both coarse and fine detritus, particularly concentrated within the upper parts of submarine valleys below the shelf edge; this stage was abruptly terminated by the initiation of a rise in base-level, which produced the thin fining-upward top to each cycle.

This depositional sequence accounts for the relatively thick, coarser component within each cycle, and also for the position of the coarsening-upward transition toward the base of each cycle (Fig. 3). The occurrence of decreased $\mathrm{CaCO}_{3}$ values toward the top of coarseningupward cycles can also be understood, as a consequence of decreased flux of shelf-derived bioclasts and concomitant increases in terrigenous clay influx that resulted from decreased shelf "carbonate factory" (James, 1979) production during sea-level lowstands.

This sedimentation style extends throughout Unit III and, based on seismic data (Feary, Symonds, et al., this volume), is likely to extend much deeper beneath the outermost shelf into the Pliocene succession. The coarsening-upward cyclicity of Unit II, although less well exhibited, probably was also deposited under a similar baselevel-controlled sedimentation regime.

The keys to understanding sedimentary processes during Unit 1 deposition are provided by isotopic and radiocarbon data from the upper part of Hole 820A (Peerdeman et al., this volume; Peerdeman and Davies, this volume). Peerdeman and Davies (this volume) used a detailed age model derived from radiocarbon data within the top $8 \mathrm{~m}$ of Hole $820 \mathrm{~A}$ to correlate isotopic data and lithofacies with an 
independently derived sea-level fluctuation record for the past 9,000 years (McLean et al., 1978; Davies and Hopley, 1983; Davies et al. 1985). This shows the anticipated close correspondence between oxygen isotope values and fluctuations in sea-level. Peerdeman and Davies (this volume) then used closely spaced oxygen isotope data to extend this relationship to the top $35 \mathrm{~m}$ of the sequence and concluded that lithofacies characteristics could be correlated with different parts of the sea-level cycle as follows:

1. Sea-level rise: initially produced a dramatically decreased proportion of coarser detritus, followed by a slight gradual increase in the proportion of coarse material. Initially, sedimentation during the transgression was relatively slow $(22 \mathrm{~cm} / \mathrm{k} . \mathrm{y}$.), but rapidly increased to $82 \mathrm{~cm} / \mathrm{k}$.y. This was matched by a significantly decreased carbonate content followed by a slight increase in $\mathrm{CaCO}_{3}$ content.

2. Sea-level highstand: resulted in muddy, $\mathrm{CaCO}_{3}$-poor deposition with moderate sedimentation rate $(50 \mathrm{~cm} / \mathrm{k} . \mathrm{y}$.).

3. Sea-level fall: produced a rapid increase in both sand-sized and carbonate components, but with a very low sedimentation rate $(3 \mathrm{~cm} / \mathrm{k} . \mathrm{y}$.) to form a condensed section.

4. Sea-level lowstand: resulted in continued highly calcareous, coarse-grained deposition.

The differences in sedimentation style between Units I and III can therefore be attributed to differences in response to sea-level fluctuations. Whereas coarse, bioclastic, sand-sized detritus was deposited during highstand, regression, and lowstand parts of the sea-level cycle during Unit III, such coarse material was only deposited during falling and low sea-level stages during Unit I sedimentation, with relatively low sedimentation rates. Conversely, the fine wackestones at the base of Unit III coarsening-upward cycles represent relatively condensed deposition during rises in sea-level, whereas the fine wackestones throughout Unit I represent relatively high rates of sedimentation during both rises and highstands of sea-level.

Sediment accumulation rates provide an important distinction between the different sedimentation styles. Whereas Unit III deposition was relatively rapid, with an average accumulation rate at the seismic sequence depocenters of $146 \mathrm{~cm} / \mathrm{k} . \mathrm{y}$. (Feary, Symonds, et al., this volume), the rate was much lower $(75 \mathrm{~cm} / \mathrm{k}$.y.) during Unit II deposition and averaged less than $20 \mathrm{~cm} / \mathrm{k} . \mathrm{y}$. throughout Unit I. Feary, Symonds, et al. (this volume) argue that these variations in sediment accumulation rate resulted from the initiation of outer Great Barrier Reef growth. These authors suggest that establishment of a reefal barrier began to affect sediment deposition on the outer shelf and upper slope at the boundary between Units III and II deposition, and was a fully effective barrier at the conclusion of Unit II deposition. They argue that the barrier essentially trapped inner shelf and terrigenous sediment inshore, and also excluded high energy events that might otherwise have eroded inner shelf detritus and moved it seaward.

This suggestion provides a consistent explanation to account for the distinctively different sedimentation styles within the Site 820 sedimentary record. At the base of the cored succession, coarse shelfal bioclastic material, together with abundant mud, could be moved offshore by shelf currents and storms essentially without impediment, with sea-level fluctuations producing a coarsening-upward cyclicity. In effect, prior to the initiation of an effective reefal barrier between $760 \mathrm{k} . \mathrm{y}$. and $1.01 \mathrm{Ma}$, sedimentation processes on the outer shelf/upper slope were essentially identical to those of siliciclastic depositional systems (e.g., Jervey, 1988), despite the sediment being dominantly carbonate. In contrast, following the formation of an effective barrier, a shelfal carbonate-factory depositional system (James, 1979) released much less coarse bioclastic detritus through the barrier onto the outermost shelf. It is likely that the abundant bioclastic material generated by shelf reefs would have been retained and reworked on the inner shelf, and only moved downslope through a few major breaks in the outer barrier reef (Feary, Symonds, et al., this volume). However, offshore and downslope movement of finer material would have been much less restricted by a barrier and would have been available in sufficient amounts to dominate Unit I sedimentation. The sedimentary characteristics of the sequence intersected at Site 820 therefore can be attributed both to sea-level fluctuations and to overall variations in the rate of sediment supply that resulted from the transition from "siliciclastic-type" to "barred carbonate-type" sedimentation.

\section{ACKNOWLEDGMENTS}

The assistance of Tony Watson, Paul Attenborough, Colin Mellor, Greg Sparksman, and John Stratton with laboratory analysis at AGSO's Marine Sedimentology Laboratory is gratefully acknowledged. Figure 2 was drafted by Jim Mason at the AGSO Cartographic Services Unit. We acknowledge reviews of the manuscript by J. Kennard (AGSO), P.J. Davies (Sydney University), and S. Stewart (ODP). Feary publishes with permission of the Executive Director, Australian Geological Survey Organisation.

\section{REFERENCES}

Davies, P.J., and Hopley, D., 1983. Growth fabrics and growth rates of Holocene reefs in the Great Barrier Reef. BMR J. Aust. Geol. Geophys., 8:237-251.

Davies, P.J., Marshall, J.F., and Hopley, D., 1985. Relationships between reef growth and sea level rise in the Great Barrier Reef. Proc. 5th Int. Coral Reef Congr., Tahiti, 3:95-104.

Davies, P.J., McKenzie, J.A., Palmer-Julson, A., et al., 1991. Proc. ODP, Init. Repts., 133: College Station, TX (Ocean Drilling Program).

Dunham, R., 1962. Classification of carbonate rocks according to depositional texture. In Ham, W.E. (Ed.), Classification of Carbonate Rocks. AAPG, 108-121.

Embry, A.F., and Klovan, J.E., 1971. A late Devonian reef tract on northeastern Banks Island, Northwest Territories. Bull. Can. Pet. Geol., 19:730-781.

Feary, D.A., Pigram, C.J., Davies, P.J., Symonds, P.A., Droxler, A.W., and Peerdeman, F., 1990. Ocean Drilling Program-Leg 133-Northeast Australia safety package. Bur. Miner. Resour. Aust. Rec., 1990/6.

Hamilton, E.L., 1979. Sound velocity gradients in marine sediments. J. Acoust. Soc. Am., 65:909-922.

James, N.P., 1979. Introduction to carbonate facies models. In Walker, R.G. (Ed.), Facies Models. Geosci. Can. Repr. Ser., 1:105-107.

Jervey, M.T., 1988. Quantitative geological modeling of siliciclastic rock sequences and their seismic expression. In Wilgus, C.K., Hastings, B.S., Posamentier, H.W., Van Wagoner, J.C., Ross, C.A., and Kendall, C.G.St.C. (Eds.), Sea-Level Changes: An Integrated Approach. Spec. Publ.-Soc. Econ. Paleontol. Mineral., 42:47-69.

McLean, R.F., Stoddart, D.R., Hopley, D., and Polach, H., 1978. Sea level change in the Holocene on the northern Great Barrier Reef. Philos. Trans. R. Soc. London A, 291:167-186.

Müller, G., and Gastner, M., 1971. The "Karbonat-bombe:" a simple device for determination of the carbonate content in sediments, soils and other materials. Neues. Jahrb. Mineral. Monatsh., 10:466-469.

Vail, P.R., Mitchum, R.M., and Thompson, S., III, 1977. Seismic stratigraphy and global changes of sea level. Part 2: the depositional sequence as a basic unit for stratigraphic analysis. In Payton, C.E. (Ed), Seismic Stratigraphy-Applications to Hydrocarbon Exploration, AAPG Mem., 26:53-97.

Abbreviations for names of organizations and publication titles in ODP reference lists follow the style given in Chemical Abstracts Service Source Index (published by American Chemical Society).

Date of initial receipt: 30 June 1992

Date of acceptance: 14 January 1993

Ms 133SR-238

\section{APPENDIX}

Grain-size distribution, calcium carbonate content, and proportion of cemented aggregates for samples analyzed are part of this study. Note that sample data were omitted if stringent error checking indicated unreliable figures. 


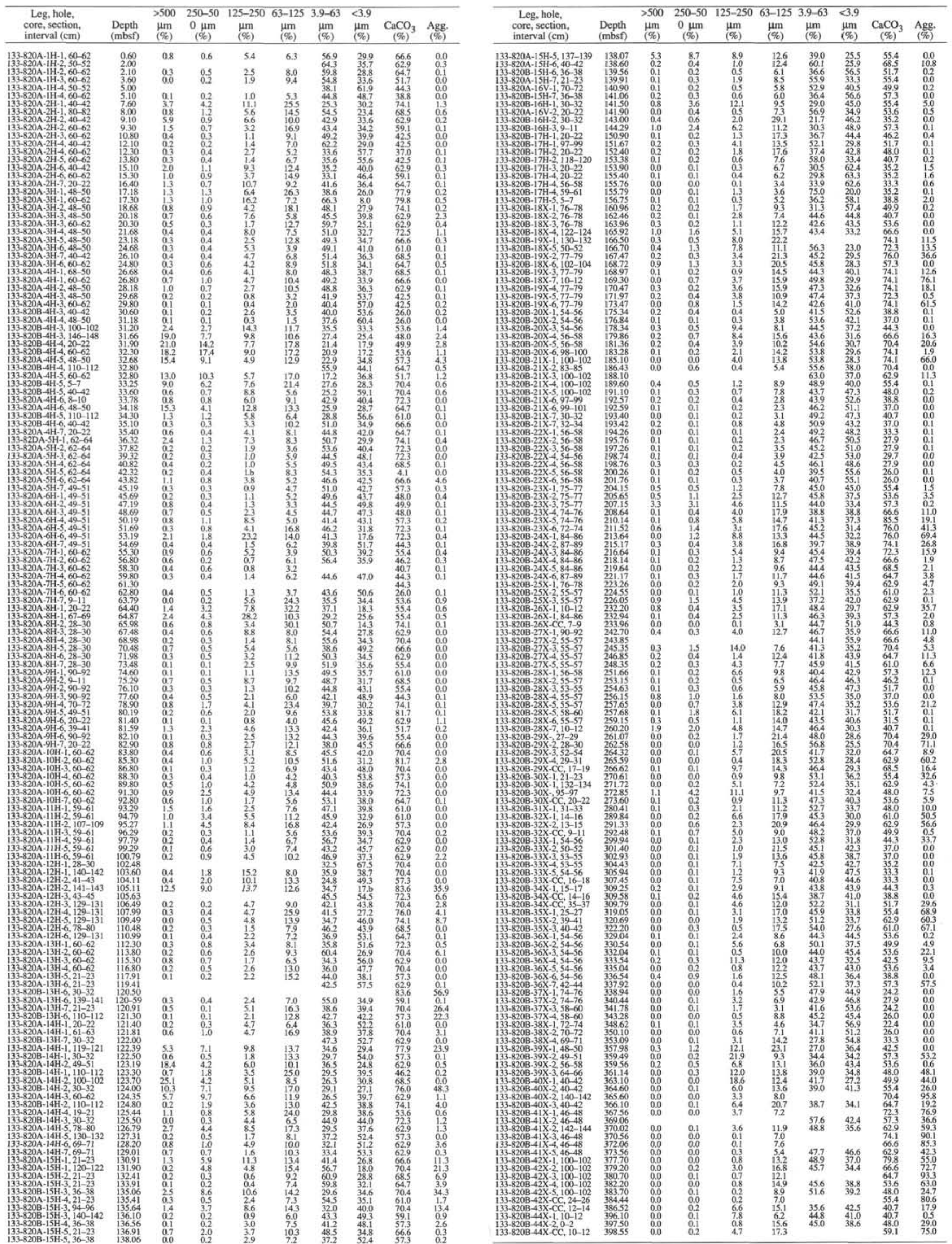

